\title{
Citizenship and Identity in Northern Ireland
}

\author{
CRG MURRAY
}

\subsection{Introduction}

Brexit, in some accounts, does not change the 1998 Agreement's citizenship provisions. The people of Northern Ireland remain able 'to identify themselves and be accepted as Irish or British, or both, as they may so choose'. ${ }^{1}$ It does not alter the obligation on the UK government to maintain rigorous impartiality between these identities in Northern Ireland's governance. ${ }^{2}$ On a deeper account, however, questions of identity in Northern Ireland are central to the idea of Brexit and have profoundly shaped the reality of Brexit. Within the Northern Ireland context, the Democratic Unionist Party (DUP)'s case for Brexit in the 2016 referendum campaign was unabashedly about restoring UK sovereignty, in the expectation that the UK 'taking back control' of lawmaking competences from the EU would intensify Northern Ireland's distinctiveness from Ireland, and that this divergence would hamper any future moves towards unification. Opposition to Brexit put the case that such an outcome would inevitably destabilize the 1998 settlement. This opposition to Brexit was not entirely determined by identity during the referendum campaign; politicians and commentators across Northern Ireland's political spectrum identified the threat Brexit posed to the North-South connections which had done so much to secure nationalist support for the 1998 arrangements. The Ulster Unionist Party's then-leader was, moreover, prescient in flagging up the compromises which these obligations would entail for the realization of Brexit. $^{3}$ This chapter considers the relationship between the Protocol and issues of identity.

11998 Agreement, Art 1(vi).

2 Ibid, Art 1(v).

${ }^{3}$ Northern Ireland Affairs Committee, Northern Ireland and the EU Referendum (2016) HC 48, para 78 . 


\subsection{The Intertwining of Identity and Brexit}

The shape of Brexit came to be determined by the UK government's efforts to make its plans fit with the 'letter and spirit' of the 1998 Agreement, at least once it accepted that EU law underpinned a range of aspects of North-South co-operation and provided the legal basis for a range of rights and equality protections within Northern Ireland. ${ }^{4}$ The Brexit negotiations over trade moved through multiple phases, with then prime minister Theresa May's UK-wide backstop giving way to Prime Minister Boris Johnson's deal which provided for Northern Ireland remaining within the EU Single Market for goods. These negotiations, accompanied by UK government paeans to the 'precious Union' ${ }^{\text {' }}$ and Irish government's concerns to preserve the 'invisible' land border, ${ }^{6}$ ratcheted up tensions around Brexit in Northern Ireland. Moving into Brexit's implementation phase, denunciations of a supposedly unionist UK government implementing a 'nationalist' deal have been added to this mix, transforming most discussions over Brexit's impacts upon Northern Ireland into a zerosum question about which identity in Northern Ireland can be said to have won. ${ }^{7}$

In addressing how Brexit has affected citizenship and identity within Northern Ireland, this chapter thus tackles a combination of issues which have resulted from Brexit and those which have been pushed to the fore by the way in which Brexit debates have been conceptualized in identity terms in Northern Ireland. First, this chapter explores how Brexit debates have become entangled with questions over the 1998 Agreement's citizenship provisions. Second, beyond the question of the choice of a national identity, if a large section of society in Northern Ireland identifies as Irish, and thus retains EU citizenship, how does Brexit threaten the rights associated with holding EU citizenship? Having examined these challenges, the chapter explores how they have been addressed both within and beyond the formal Brexit deal.

${ }^{4}$ EU Commission, 'Communication from the Commission to the European Council (Article 50) on the State of Progress of the Negotiations with the United Kingdom under Article 50 of the Treaty on European Union', $\operatorname{COM}(2017)$ 847, 08.12.2017, p 9.

5 M Edwards, 'May: Brexit Deal Must Protect "Precious Union" with Northern Ireland' Belfast Telegraph (14 May 2018).

${ }^{6}$ C Kelpie, 'Coveney Reveals His Plan for Invisible Border with North' Irish Independent (23 June 2017).

7 V Bogdanor, 'There Is a Solution to the Irish Border Problem' The Telegraph (5 February 2021). 


\subsection{The Birthright of the People of Northern Ireland}

Under the 1998 Agreement, the people of Northern Ireland are able to choose whether they assert British or Irish identity, or both. This was not a particularly contentious element of the negotiations leading to the 1998 Agreement, given that Irish law had long permitted people born in Northern Ireland to claim Irish citizenship ${ }^{8}$ and successive UK governments had accepted this entitlement. ${ }^{9}$ Irish and UK government officials drew up the conditions for the exercise of this 'birthright'. ${ }^{10}$ The lack of contention around these arrangements meant that there was no clear consensus over whether they were intended to merely confirm the UK's acceptance of Ireland's extraterritorial assertion of nationality law or were instead intended to decouple nationality law from statehood in the Northern Ireland context. The framing of these provisions in the 1998 Agreement, moreover, potentially supported the more expansive interpretation and, against the backdrop of Brexit debates, concerns intensified over the implications for UK nationality law of these 'birthright' provisions.

The British Nationality Act 1981 ensures that anyone born in Northern Ireland to a parent who is settled or is a British citizen automatically becomes a British citizen. ${ }^{11}$ It was not altered in light of the 1998 Agreement. The people of Northern Ireland can thus identify as Irish and can assert their entitlement to Irish citizenship, but if they do, they will be treated in domestic law as dual citizens unless they also take steps to renounce British citizenship. Questions over whether this sufficed for the implementation of the 1998 Agreement were latent for years because the assertion of these different categories of citizenship did not result in operative distinctions between people with these different statuses. In 2012, however, the UK government excluded British citizens who held dual nationality with another EU state from availing themselves of EU law's residency rules for third-country national family members of EU citizens. ${ }^{12}$ Because the people of Northern Ireland were automatically

8 See Irish Nationality and Citizenship Act 1956, s 7(1), and prior to that the Re Logue [1933] 67 ILTR 253 interpretation of the Constitution of the Irish Free State (Saorstát Eireann).

9 See A Harvey, 'British or Irish or Both?' (2020) 34 Journal of Immigration Asylum and Nationality Law 216, 225.

${ }^{10}$ Above (n 1), Annex 2 Declaration.

11 British Nationality Act 1981 (UK), ss 1(1) and 50(2).

12 Immigration (European Economic Area) (Amendment) Regulations 2012 (SI 2012/1547) (UK). This change followed the CJEU ruling in Case C-434/09 McCarthy $v$ Secretary of State for the Home Department [2011] ECR I-03375. 
presumed to be British citizens, this change meant that they could no longer circumvent minimum income requirements for securing the residency of family members by asserting their Irish citizenship, unless they also renounced their British citizenship. ${ }^{13}$

The years following this change saw a pronounced increase in the number of people in Northern Ireland renouncing their British citizenship, leading the UK government to accept that these rules incentivized some in Northern Ireland to renounce British citizenship. ${ }^{14}$ This recognition, however, came only after Emma DeSouza forced the issue onto the agenda when these rules impacted upon the ability of her spouse, Jake, a United States citizen, to secure residency documents. The DeSouzas did not, as others in their circumstances had done, simply renounce Ms DeSouza's underlying British citizenship but alleged that its automatic imposition under the British Nationality Act was a breach of the 1998 Agreement's birthright provisions. ${ }^{15}$

The Upper Tribunal, however, rejected this challenge on the basis that the 1998 Agreement, as an unincorporated treaty, could not affect the interpretation of the British Nationality Act $1981 .{ }^{16}$ It furthermore concluded that the Agreement 'does not, in fact, involve giving the concept of self-identification the meaning for which the claimant argues', justifying this conclusion on the basis that, if that meaning had been intended, the Agreement would have been much more explicit about the impact of its terms. ${ }^{17}$ This is best regarded as obiter dicta, as there was little need for the Tribunal to step into this territory given that it had already determined to give no weight to the Agreement as an unincorporated treaty.

This has not prevented further litigation on the impact of the 1998 Agreement's birthright provision on UK nationality law, notably Irish citizen Lisa Smith's challenge against her exclusion from the UK on the basis of her connections with Islamic State. In response to Smith's preliminary claims to dual nationality based on her father being Belfastborn, the Special Immigration Appeals Commission ruled that it would be discriminatory for the Home Secretary to deny her this entitlement on

13 The current minimum income threshold is an annual income of $£ 18,600$; Immigration Rules (UK) HC 395, Appendix FM-SE.

14 B Lewis MP, Hansard, HC, WA471, 15 January 2020.

15 See S de Mars and C Murray, 'With or Without EU? The Common Travel Area after Brexit' (2020) 21 German Law Journal 815, 823-24.

16 Secretary of State for the Home Department v Jake Parker De Souza [2019] UKUT 355, para 28.

17 Ibid, para 39. 
the basis that Smith's parents were not married when she was born. The Commission nonetheless maintained that the obligation on someone claiming to have entitlement to British citizenship to take an oath and pledge of allegiance is not inconsistent with the rights of those who wish to identify as Irish' under the 1998 Agreement. ${ }^{18}$ Smith's eagerness to assert dual nationality to prevent exclusion highlights how different claimants are drawing upon very different accounts of how nationality law works in the context of Northern Ireland.

\subsection{Brexit and 'EU Rights, Opportunities and Benefits'}

The instability in understandings of the 1998 Agreement's citizenship provisions exacerbated tensions and confusions around Brexit and identity. The entitlement of the people of Northern Ireland to Irish, and therefore EU, citizenship would continue post-Brexit, but for long periods within the Brexit negotiations there was very little clarity as to what this would mean in practice. The 2017 UK-EU Joint Report, for example, included promises about the continuation of EU citizenship rights for Irish citizens living in Northern Ireland after Brexit. ${ }^{19}$

Airy pledges to 'examine' the continuation of these 'EU rights, opportunities and benefits' soon ran into practical challenges. EU citizenship, put simply, means much less when someone is resident outside the EU member states, and the EU was not about to restructure understandings of EU citizenship and EU law rights to accommodate Northern Ireland. Commitments to working on arrangements for protecting the 'EU rights, opportunities and benefits' of those people of Northern Ireland who had asserted their Irish citizenship might have appeared to reflect commitments to non-diminution of 1998 Agreement rights. If special protections were created for this particular group, however, this would collide with another 1998 Agreement principle, that of parity of esteem for those asserting British and Irish identities in Northern Ireland. Singling out a particular group of EU citizens in Northern Ireland for these protections would also run into issues of discrimination under EU law.

${ }_{18}$ Smith $v$ Secretary of State for the Home Department (2021) SC/169/2020, para 49.

19 Joint Report from the Negotiators of the European Union and the United Kingdom Government on Progress during Phase 1 of Negotiations under Article 50 TEU on the United Kingdom's Orderly Withdrawal from the European Union (8 December 2017) para 52. 
These difficulties highlight that both the EU and the UK struggled to accommodate Brexit within the strictures of the 1998 Agreement. The broad terms of the 2017 UK-EU Joint Report's commitment would be reflected in the Preamble to the Protocol, which states that it will operate 'without prejudice to the rights, opportunities and identity that come with citizenship of the Union for the people of Northern Ireland who choose to assert their right to Irish citizenship'. In operative terms, however, Protocol Article 2 provided for more limited commitments to maintain the operation of only those elements of EU law in Northern Ireland which could be shown to underpin the 'Rights, Safeguards and Equality of Opportunity' section of the 1998 Agreement, which does not cover the 'birthright' guarantee. ${ }^{20}$

Nor does the EU settlement scheme operating under the terms of the Withdrawal Agreement (WA) apply to dual nationals with British citizenship. ${ }^{21}$ The people of Northern Ireland therefore did not have the opportunity to register under the scheme to protect the 'rights, opportunities and benefits' associated with EU citizenship unless they had taken active steps to renounce their underlying British citizenship. Irish citizens outwith the people of Northern Ireland, who enjoy entitlements associated with the Common Travel Area (CTA), were long discouraged from applying under the scheme. ${ }^{22}$ Multiple classes of rights holder were thus created by the WA and UK government policy, and the associated difficulties of administering the different rights and entitlements, which are linked to subtle differences of status, are likely to emerge over the years to come.

\subsection{Mitigations}

If the apparent promise of the Joint Committee report was far from being realized in the WA's terms, the Protocol's aspiration in its Preamble to protect EU-law related 'rights, opportunities and benefits' continued to shape the aftermath of Brexit. Some of these issues would be addressed as part of the future relationship negotiations, leading to the Trade and Cooperation Agreement (TCA). But others would not be, and, as

${ }^{20}$ See Chapter 12.

${ }^{21}$ UK Home Office, EU Settlement Scheme: EU, Other EEA and Swiss Citizens and Their Family Members (version 11, April 2021) p 14.

${ }^{22}$ Its potential importance for their family residency rights was recognized only belatedly by a Home Office minister; Baroness Williams of Trafford, Hansard, HL, vol 805, col 629 (7 September 2020). 
negotiations towards the TCA went down to the wire in December 2020, Ireland was preparing to step in with unilateral measures to safeguard against sudden shortfalls. ${ }^{23}$

Two high-profile concerns regarding the people of Northern Ireland's EU 'rights, opportunities and benefits' which remained unclear before the conclusion of the TCA were the post-Brexit operation of the European Health Insurance Card (EHIC) and that of the Erasmus+ scheme. The former issue was settled as part of the TCA; $;^{24}$ the people of Northern Ireland would appear to have comparable entitlements using the UK's new Global Health Insurance Card when travelling to EU member states to those they had enjoyed under EHIC. ${ }^{25}$ The UK government did not, however, reach an agreement with the EU regarding the continuation of the Erasmus+ scheme. Ireland has thus committed to put in place arrangements and funding for students at Northern Ireland higher education institutions to register temporarily with institutions in Ireland to allow them to continue to use Erasmus+. ${ }^{26}$

Ian Paisley Jr's unapologetic 'fill-your-boots' response to Ireland's preparations regarding EHIC and Erasmus+ was to ask the Northern Ireland Secretary, '[i]s there anything else we can get the Irish Government to pay for ...?? ${ }^{27}$ This was, of course, to miss the point of these developments. They were driven by a specific imperative to address an expected shortfall in EU 'rights, opportunities and benefits' for the people of Northern Ireland arising because of Brexit. Given that there is no EU citizenship connection to people of Northern Ireland who identify solely as British, it is appropriate that such issues be addressed by unilateral or bilateral action by the Irish and UK governments. These developments are thus primarily shaped by concerns to ensure non-diminution of rights, but also demonstrate the influence of other 1998 Agreement principles. That the Irish government never suggested a scheme applicable only to Irish citizens studying at Northern Ireland institutions

${ }^{23}$ See L Varadkar TD, Dáil Debates, 17 September 2019, p 15.

${ }^{24}$ See Chapter 14.

25 Trade and Cooperation Agreement between the United Kingdom of Great Britain and Northern Ireland, of the one part, and the European Union and the European Atomic Energy Community of the other part (1 May 2021) CP 426, Protocol on Social Security Coordination, Art SSC.15-20. A person of Northern Ireland who has formally renounced British citizenship can, as an EU citizen resident in the UK, continue to apply for an EHIC card if they avail themselves of the EU settlement scheme.

${ }^{26}$ S Harris TD, Dáil Debates, 13 January 2021, WA 1097/21.

27 Northern Ireland Affairs Committee, Oral Evidence: Work of the Secretary of State for Northern Ireland (20 January 2021) HC 264, Q11 3. 
demonstrates the underlying impact of 'parity of esteem'. ${ }^{28}$ These 1998 Agreement principles, in combination, are shaping these mitigations of Brexit's impacts on Northern Ireland.

Their influence is also evident in the ultimate defusal of the DeSouza litigation. The UK government promised a response under the New Decade, New Approach deal which paved the way to restarting powersharing government in Northern Ireland in January $2020 .^{29}$ Thereafter, the DeSouzas' appeal against the Upper Tribunal's decision was withdrawn after the UK government announced changes to Appendix EU of the immigration rules. ${ }^{30}$ Under these changes, between 24 August 2020 and the end of the EU settlement scheme in 30 June 2021, 'third-country' family members of someone who met the 1998 Agreement definition of a person of Northern Ireland may apply for residence in the UK under the same terms as individuals eligible to do so under the settlement scheme.

For Austen Morgan, the UK government, despite its success before the Upper Tribunal, 'behaved like a loser' in this response. ${ }^{31}$ The amendment to Appendix EU is not, however, a response that gives any ground on the automatic ascription of British citizenship under the British Nationality Act 1981. Indeed, the UK government has reasserted that it is of the firm view that UK nationality law is consistent with its obligations under the Belfast Agreement obligations and the ECHR [European Convention on Human Rights]'. ${ }^{32}$ That conclusion is, at least, questionable given that the costs for persons of Northern Ireland of $£ 372$ to renounce their underlying British citizenship constrain their ability to make, and 'be accepted' in, their citizenship choices. ${ }^{33}$ The mitigation introduced following New

${ }^{28}$ Ireland's responses are also shaped by its EU law obligations; the proposed replacement for the EHIC card would have extended to EU citizens resident in Northern Ireland to ensure that they were not disadvantaged on grounds of nationality. See S de Mars, C Murray, A O'Donoghue and B Warwick, Continuing EU Citizenship 'Rights, Opportunities and Benefits' in Northern Ireland after Brexit (Irish Human Rights and Equality Commission/Northern Ireland Human Rights Commission 2020) 52-53.

${ }^{29}$ New Decade, New Approach (January 2020) Annex A, paras 13-15.

30 Statement of Changes in Immigration Rules (14 May 2020) CP 232.

31 Written Evidence to the Northern Ireland Affairs Committee's Citizenship and Passport Processes in Northern Ireland Inquiry (February 2021) para 40.

32 Written Evidence to the Northern Ireland Affairs Committee's Citizenship and Passport Processes in Northern Ireland Inquiry (March 2021) p 3.

33 See A Harvey, A Legal Analysis of Incorporating into UK Law the Birthright Commitment under the Belfast (Good Friday) Agreement 1998 (Irish Human Rights and Equality Commission/Northern Ireland Human Rights Commission 2020) p 46. 
Decade, New Approach does nothing in the medium to long term to address these concerns over the implementation of the birthright following DeSouza.

It instead addresses the distinct issue of the holders of some citizenship statuses within the people of Northern Ireland being advantaged over others. Persons of Northern Ireland who are dual citizens are not enabled to take part in the EU settlement scheme; their 'third-country' family members can instead establish residency rights as if they were related to someone covered by the settlement scheme. This approach appears to be derived from the EU settlement scheme provisions adopted to address people with EU rights derived from the CJEU's Lounes judgment. ${ }^{34}$ It did not restore the British citizenship of anyone who had previously taken steps to renounce it to secure residency rights for a family member, and the provision expired with the EU settlement scheme. It is thus unlikely to benefit more than a handful of people. But it did give the concept of the 'person of Northern Ireland' temporary significance within UK immigration law, which could be drawn upon again. ${ }^{35}$ Such an approach, entirely removed from the EUlaw basis of the residency rights at issue, reads equality of treatment obligations into the operation of the birthright. ${ }^{36}$

This approach also has implications for the shape of citizenship should Irish (re)unification come to pass. Under the 1998 Agreement, the ability of the people of Northern Ireland 'to hold both British and Irish citizenship is accepted by both Governments and would not be affected by any future change in the status of Northern Ireland'. ${ }^{37}$ The ongoing commitment within the 1998 Agreement is, thus, to facilitate entitlements to dual citizenship; it is not to protect the right to be Irish or British or both. Given the reception to the DeSouzas' claims by UK institutions, there would seem to be little basis for opposing a future Irish government imposing underlying Irish citizenship on people born within the territory of the state after (re)unification to parents who are, or who are entitled to

${ }^{34}$ C-165/16 Lounes $v$ Secretary of State for the Home Department (2017) EU:C:2017/862. See also above (n 21), p 18.

35 See B Ryan, 'Recognition after All: Irish Citizens in Post-Brexit Immigration Law' (2020) 34 Journal of Immigration Asylum and Nationality Law 284, 301.

36 From 1998 onwards the UK government should have recognized that the Agreement posed challenges for any applications of law, including residency rights under EU law, which advantaged parts of the people of Northern Ireland over others on nationality grounds.

37 Above (n 1), Art 1(vi). 
be, Irish citizens. ${ }^{38}$ As for renunciation, although Irish law provides for renunciation of citizenship with no associated fees, this presently applies only to adults not ordinarily resident within the state. ${ }^{39}$

\subsection{No Petty People}

In 1925, WB Yeats thundered in the Seanad that the Anglo-Irish were 'no petty people', as divorce was abolished and with it, for him, the hope that the Irish Free State would protect interests beyond those promoted by the Catholic Church. ${ }^{40}$ The people of Northern Ireland, by contrast, can scarcely be described as a people at all. Yet the 1998 Agreement accepted this formula and, moreover, imbued this people with citizenship rights and a level of constituent power unique within the UK's constitutional order (although how the group was defined was not necessarily the same in both instances).

There was a hope that, with decades of stable governance, rebuilt institutions and effective support for 'parity of esteem' from civil society that a people of Northern Ireland could develop after the 1998 Agreement. ${ }^{41}$ And there are many more people in Northern Ireland today who do not connect their identity primarily to the constitutional question over Northern Ireland's status than there were in the late 1990s. ${ }^{42}$ The 1998 Agreement threw the ball over the wall and expected that society in Northern Ireland would follow suit. But it was no more possible for the ending of legal impediments upon women to bring about gender equality in and of itself than for the 1998 Agreement to be the sole, or even main, vehicle of change in Northern Ireland. Its transformative potential had to be nurtured. Instead, vacillation over the legacy of the conflict and over whether measures promoting the Irish language should be introduced has been pushing identity to the fore in Northern Ireland's politics, a development which Brexit has exacerbated.

${ }^{38}$ Constitution of Ireland/Bunreacht na hÉireann, Art 9.2. Imposing Irish citizenship on living people of Northern Ireland without consent would be a different proposition, and would raise Art 8 ECHR issues, even if existing case law on citizenship and Art 8 is more developed with regard to denial and renunciation.

39 Irish Nationality and Citizenship Act 1956 (Ireland), s 21(1).

40 Seanad Éireann Debates, 11 June 1925, Speech \#82.

${ }^{41}$ See C Murray, 'The Constitutional Significance of the People of Northern Ireland' in O Doyle, A McHarg and J Murkens (eds), The Brexit Challenge for Ireland and the United Kingdom: Constitutions under Pressure (Cambridge University Press 2021) 108, 119.

42 See K Hayward and C McManus, 'Neither/Nor: The Rejection of Unionist and Nationalist Identities in Post-Agreement Northern Ireland' (2019) 43 Capital \& Class 139. 


\subsection{Conclusion}

Brexit found Northern Ireland in a state of destabilized governance and in the midst of a process of societal transformation. Divisions that had been papered over by the peace process were reopened by this zero-sum play for a pure UK sovereignty. The tortured process of realizing Brexit, in which issues around Northern Ireland repeatedly came to the fore, inevitably exacerbated tensions over identity within Northern Ireland's populace. To this inevitable shock have been added distortions and obfuscation about what the Brexit outcomes agreed by the UK government mean for Northern Ireland. ${ }^{43}$ All of these developments have worked to reassert core identities. And yet, through it all, individuals and civil society in Northern Ireland have been able to influence the negotiations and harness the principles underpinning the 1998 Agreement to resolve some of Brexit's immediate challenges around citizenship. ${ }^{44}$ Maybe the people of Northern Ireland can indeed claim to be no petty people.

${ }^{43}$ Arts 4 and 5 of the Protocol involve a remarkable sleight of hand, compounded by the UK government's efforts to downplay the significance of barriers to trade in between Great Britain and Northern Ireland; C Murray and C Rice, 'Into the Unknown: Implementing the Protocol on Ireland/Northern Ireland' (2020) 15 Journal of Cross-Border Studies in Ireland 17, 20-21.

${ }^{44}$ See S de Mars and A O'Donoghue, 'Beyond Matryoshka Governance in the Twenty-First Century: The Curious Case of Northern Ireland' in O Doyle, A McHarg and J Murkens (eds), The Brexit Challenge for Ireland and the United Kingdom: Constitutions under Pressure (Cambridge University Press 2021) 64, 66. 